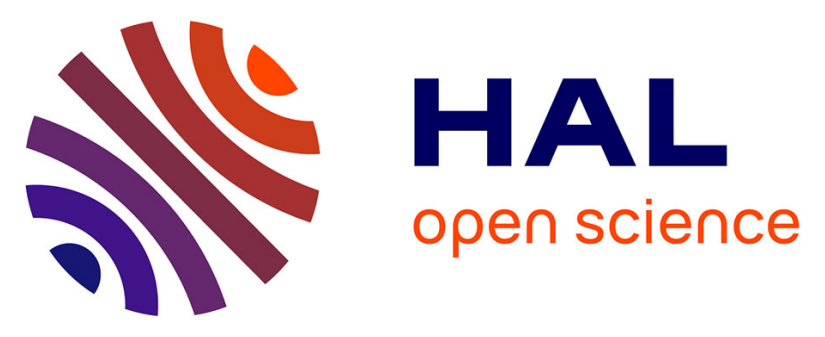

\title{
The use of concept maps in the therapeutic patient education field: preliminary study with an analysis of the litterature
}

Marie Godet, Claire Marchand, Vincent de Andrade, Jean -François D

'Ivernois, Rémi Gagnayre

\section{To cite this version:}

Marie Godet, Claire Marchand, Vincent de Andrade, Jean -François D 'Ivernois, Rémi Gagnayre. The use of concept maps in the therapeutic patient education field: preliminary study with an analysis of the litterature. Educ Ther Patient/Ther Patient Educ, 2015, 7 (2), pp.20103. 10.1051/tpe/2015014 . hal-01568261

\section{HAL Id: hal-01568261 \\ https://sorbonne-paris-nord.hal.science/hal-01568261}

Submitted on 25 Jul 2017

HAL is a multi-disciplinary open access archive for the deposit and dissemination of scientific research documents, whether they are published or not. The documents may come from teaching and research institutions in France or abroad, or from public or private research centers.
L'archive ouverte pluridisciplinaire HAL, est destinée au dépôt et à la diffusion de documents scientifiques de niveau recherche, publiés ou non, émanant des établissements d'enseignement et de recherche français ou étrangers, des laboratoires publics ou privés. 


\title{
Article original/Original article
}

\section{The use of concept maps in the therapeutic patient education field: preliminary study with an analysis of the litterature}

\author{
Marie Godet ${ }^{1}$, Claire Marchand ${ }^{2 \star}$, Vincent De Andrade ${ }^{2}$, Jean-François d'Ivernois², Rémi Gagnayre ${ }^{2}$ \\ 1 Surgical unit, CHI Poissy Saint-Germain-en-Laye, France \\ 2 Laboratory Educations and Health Practices, EA 3412, University Paris 13 Sorbonne Paris Cité, Bobigny, France
}

(Received 3 September 2015, accepted 26 October 2015)

\begin{abstract}
Introduction: The concept map (CM) is a teaching technique that aids learning and its assessment Originally used in general education, it was introduced in therapeutic patient education (TPE) in 2004. Aims: To describe and analyse the use of concept mapping in TPE ten years after its introduction. Methods: Analysis of the literature from 2004 to 2014 using the following databases and search engines: ScienceDirect, Google Scholar, PubMed, EMPremium, PsycINFO, OpenGrey, Sudoc, ERIC and JSTOR. Results: Twenty-seven documents were analyzed. Twentyone of these reported studies or practical experiences in France. The maps were used in TPE for different groups having a variety of conditions, mainly for the purpose of diagnostic and training assessments (23/27), and less commonly as a learning aid (4/27). Several methods for use were identified: construction by the patient, by the educator, as a group or individually. The authors described the benefits of each method. The effects and educational potential of concept mapping were discussed. Conclusion: Despite the limited number of publications, this literature analysis confirms the value of concept maps in TPE. However, their use, which is still limited, will depend on whether caregiver-educators see a place for them and are trained to use them.
\end{abstract}

Key words: concept map / therapeutic patient education / patient education / literature review

Résumé - L'utilisation des cartes conceptuelles dans le champ de l'éducation thérapeutique des patients : étude préliminaire à partir d'une analyse de la littérature. Introduction : La carte conceptuelle est une technique pédagogique favorisant l'apprentissage et son évaluation. Utilisée initialement en éducation générale, elle a été introduite dans le domaine de l'éducation thérapeutique des patients (ETP) en 2004. Objectifs : Décrire et analyser les utilisations de la carte conceptuelle en ETP 10 ans après leur introduction dans ce champ Méthode : Analyse de la littérature entre 2004 et 2014 à partir de plusieurs bases de données et moteurs de recherche : Science Direct, Google Scholar, Pub Med, EM-Consult, PsyInfo, Open Grey, Sudoc, ERIC, JSTOR. Résultats : Vingt-sept documents ont été analysés. 21/27 sont des études ou expériences pratiques menées en France. Les cartes sont utilisées en ETP auprès de différents publics porteurs de pathologies diverses. Elles sont principalement utilisées dans un but d'évaluations diagnostique et formative (23/27) et moins souvent comme technique d'aide à l'apprentissage (4/27). Plusieurs modalités d'utilisation sont retrouvées : réalisation par le patient, par l'éducateur, en groupe ou individuellement. Les avantages de chaque modalité sont décrits par les auteurs. Les effets et potentialités pédagogiques des cartes conceptuelles sont relevés. Conclusion : Malgré un nombre limité de publication, cette analyse de la littérature confirme l'intérêt des cartes conceptuelles dans le champ de l'ETP. Cependant, leur utilisation, encore limitée, reste dépendante de la place que leur accordent les soignants éducateurs pour favoriser l'apprentissage des patients et de leur formation à leur utilisation.

Mots clés : carte conceptuelle / éducation thérapeutique du patient / éducation du patient / revue de littérature

\section{Introduction}

The concept map (CM) is a teaching technique that aids learning and its assessment It allows a person to organize and schematically represent his knowledge starting from a central

\footnotetext{
^ Correspondence: claire.marchand@univ-paris13.fr
}

concept [1]. Once finished, it is made up of concepts (objects, events, ideas, etc.) interconnected by word links, forming propositions. It thereby shows an individual's knowledge and representations and how they are organized.

First introduced in the general education field to foster "meaningful learning" - as opposed to "rote learning" - concept maps have since been used in many different fields. The 
growing interest in concept mapping became apparent in 2004 at the first International Conference on Concept Mapping, which has since become a biennial event supported by the Institute for Human and Machine Cognition (IHMC), (http:// cmc.ihmc.us/). It brings together teachers and educators from different disciplines, researchers and scientists, attesting to how widely the technique has spread internationally. As can be seen on the IHMC website, concept maps are used everywhere from elementary schools to higher education institutions for learning, assessment and knowledge modeling in such varied areas as mathematics, languages, biology, music, health training, research, etc. A 2006 meta-analysis of 55 studies showed the effects of using concept maps on learning [2]. The authors concluded that whatever the education level, method used or area studied (physical sciences, psychology, statistics or health sciences, to give an idea of the wide variety of learning areas), concept mapping improved knowledge memorization compared to other learning strategies. No negative effects from its use had been found. The authors did, however, stress that there was insufficient evidence regarding its effects on knowledge transfer - that is, its use in problem solving - and on skill development [2].

In a 2004 article summarizing the use of concept maps in training healthcare professionals, Marchand and d'Ivernois [3] argued for the use of concept mapping in therapeutic patient education (TPE) based on earlier research in this area $[4,5]$. In therapeutic education, patients are considered learners who must acquire the knowledge and skills they need to manage - and live as well as possible with - their disease. The first studies to look at both CM and TPE used the methods for constructing concept maps described by Novak and Gowin [1], starting from a central concept and creating a concept map based on what the learner says, with no pre-existing structure [4,5] (Fig. 1, Tab. I). Marchand and d'Ivernois [3] then considered other methods and reported their own experience of the use of CM. Thus in 2004, concept mapping was a new area of research and application in therapeutic patient education. Given the significant increase in the use of concept mapping for training and education in a whole range of disciplines since then, we were curious about its status, ten years later in the context of TPE practice: how is it used? For which purposes? How does it contribute to TPE, from the user's perspective? To answer these questions, we analyzed the writings of researchers and practitioners identified using a number of databases and search engines.

\section{Methods}

A literature search was done starting from 2004, the year the summary article on the use of concept mapping in training health professionals [3] was published. Aside from the two previously-mentioned studies $[4,5]$, that article may be considered one of the first to attract the community's attention to the possible use of concept mapping in therapeutic patient education.
We consulted several databases and search engines: ScienceDirect, Google Scholar, PubMed, EM-Premium, PsycINFO, OpenGrey, Sudoc, ERIC and JSTOR.

The French keywords used and the corresponding English terms were as follows: éducation thérapeutique du patient, éducation du patient (patient education, self care, self management, therapeutic education); maladie chronique (chronic disease, chronic illness, chronic disorder); carte conceptuelle, and carte sémantique (concept map, concept mapping, mind map, mind mapping, semantic map, semantic mapping).

The search criteria were as follows: all articles and oral presentation abstracts published in English- and Frenchlanguage journals from 2004 to 2014 on the use of concept mapping in therapeutic patient education (Fig. 2).

Publications were selected by two independent researchers based on their titles and abstracts. Documents that did not discuss the use of concept maps for the purposes of therapeutic patient education were excluded.

Any disagreements about the selection were discussed; if necessary, a third reader was consulted.

As the first search yielded only a limited number of articles and presentations, we asked for input from a network of health professional trainers who had supervised the theses or dissertations of health professionals using concept mapping in TPE over the same time period.

The analysis attempted to identify, for each document:

- The main characteristics of the selected documents: the country, the type of document, and the context in which concept mapping was used (study or practical experience). By studies we mean both research studies and evaluations asking for the users' or beneficiaries' viewpoint. Practical experience corresponds - in the documents selected - to the personal viewpoint of a concept map user.

- The conditions of CM use: the purposes for which the CMs were used, with reference to the steps in the TPE process [6]: diagnosis, contract, education sessions during which learning aids are used, educational assessment and educational follow-up; the audience benefitting from CMs; and the construction methods and their advantages and disadvantages, as indicated by the authors.

- The effects, educational potential and limitations of concept mapping, according to the authors.

\section{Results}

\subsection{Main characteristics of the documents analyzed}

Twenty-seven documents were included in the analysis (Tab. I):

- In order of frequency, they concerned studies or practical experiences from France (21), Switzerland (3), Italy (1), Finland (1), England (1) and Iran (1). A third of the articles (9/27) were published in English. 
Table I. Characteristics of the selected documents from 2004 to $2014(N=27)$.

\begin{tabular}{|c|c|c|c|c|c|c|c|}
\hline & \multicolumn{4}{|c|}{ Main document characteristics } & \multicolumn{3}{|c|}{ Conditions in which concept maps were used } \\
\hline Reference & Country & $\begin{array}{l}\text { Document } \\
\text { type }\end{array}$ & $\begin{array}{c}\text { Context in } \\
\text { which } C M \\
\text { used }\end{array}$ & $\begin{array}{c}\text { Purpose for } \\
\text { which CM } \\
\text { used }\end{array}$ & Pathology & $T$ & $\begin{array}{c}\text { Method for } \\
\text { constructing the CM }\end{array}$ \\
\hline $\begin{array}{c}\text { Pinosa } \\
\text { et al., } \\
2004[24]\end{array}$ & France & Article & $\begin{array}{l}\text { Qualitative } \\
\text { study }\end{array}$ & Assessment & Diabetes & $\begin{array}{l}\text { Children } \\
(N=5)\end{array}$ & $\begin{array}{c}\mathrm{CM}+\text { interview by } \\
\text { researcher, before and } \\
\text { after TPE }\end{array}$ \\
\hline $\begin{array}{c}\text { França } \\
\text { et al., } \\
2004[17]\end{array}$ & Switzerland & Article & $\begin{array}{l}\text { Mixed } \\
\text { study }\end{array}$ & Assessment & $\begin{array}{c}\text { Diabetes, } \\
\text { overweight }\end{array}$ & $\begin{array}{l}\text { Adults } \\
(N=8)\end{array}$ & $\begin{array}{c}\mathrm{CM}+\text { interview by } \\
\text { researcher, before and } \\
\text { after TPE }\end{array}$ \\
\hline $\begin{array}{l}\text { Rébérot } \\
\text { Amory, } \\
2004 \text { [39] }\end{array}$ & France & Thesis & $\begin{array}{l}\text { Qualitative } \\
\text { study }\end{array}$ & Diagnosis & Diabetes & $\begin{array}{c}\text { Adults } \\
(N=15)\end{array}$ & $\begin{array}{l}\mathrm{CM}+\text { interview by } \\
\text { educator, before TPE }\end{array}$ \\
\hline $\begin{array}{c}\text { Arnal, } \\
2006[11]\end{array}$ & France & Thesis & $\begin{array}{c}\text { Practical } \\
\text { experience }\end{array}$ & Assessment & Hemophilia & $\begin{array}{l}\text { Children } \\
(N=10)\end{array}$ & CM by the child \\
\hline $\begin{array}{l}\text { Bonadimam } \\
\text { et al., } \\
2006[12]\end{array}$ & Italy & Article & $\begin{array}{c}\text { Practical } \\
\text { experience }\end{array}$ & Diagnosis & Asthma & $\begin{array}{c}\text { Adults } \\
(N=2 / 17)\end{array}$ & $\begin{array}{c}\text { CM by the patient, } \\
\text { before TPE }\end{array}$ \\
\hline $\begin{array}{l}\text { Johansson } \\
\text { et al., } \\
2007 \text { [22] }\end{array}$ & Finland & Article & $\begin{array}{c}\text { Quantitative } \\
\text { study } \\
\text { RCT }\end{array}$ & $\begin{array}{c}\text { Educational } \\
\text { technique }\end{array}$ & $\begin{array}{l}\text { Orthopedic } \\
\text { surgery }\end{array}$ & $\begin{array}{c}\text { Adults } \\
(N=123)\end{array}$ & $\begin{array}{c}\mathrm{CM}+\text { interview by } \\
\text { researcher during } \\
\text { TPE }\end{array}$ \\
\hline $\begin{array}{l}\text { Marchand } \\
\text { et al., } \\
2007 \text { [28] }\end{array}$ & France & Article & $\begin{array}{l}\text { Qualitative } \\
\text { study }\end{array}$ & Assessment & Diabetes & $\begin{array}{l}\text { Children } \\
(N=5) \\
\text { Parents } \\
(N=5)\end{array}$ & $\begin{array}{l}\mathrm{CM}+\text { interview by } \\
\text { researcher, before and } \\
4 \text { months after }\end{array}$ \\
\hline $\begin{array}{l}\text { Marchand } \\
\text { et al., } \\
2007[13]\end{array}$ & France & Article & $\begin{array}{c}\text { Quantitative } \\
\text { study }\end{array}$ & Assessment & Obesity & $\begin{array}{c}\text { Adults } \\
(N=30)\end{array}$ & $\begin{array}{l}\mathrm{CM}+\text { interview by } \\
\text { researcher, after TPE }\end{array}$ \\
\hline $\begin{array}{c}\text { Walker } \\
\text { et al., } \\
2007 \text { [23] }\end{array}$ & UK & Article & $\begin{array}{c}\text { Quantitative } \\
\text { study } \\
\text { RCT }\end{array}$ & $\begin{array}{c}\text { Educational } \\
\text { technique }\end{array}$ & $\begin{array}{c}\text { Rheumatoid } \\
\text { arthritis }\end{array}$ & $\begin{array}{c}\text { Adults } \\
(N=363)\end{array}$ & $\begin{array}{l}\text { CM informational } \\
\text { material provided to } \\
\text { the patient, } \\
\text { constructed by the } \\
\text { educator prior to TPE }\end{array}$ \\
\hline $\begin{array}{l}\text { Michaud } \\
\text { et al., } \\
2008 \text { [9] }\end{array}$ & France & Article & $\begin{array}{l}\text { Qualitative } \\
\text { study }\end{array}$ & $\begin{array}{c}\text { Educational } \\
\text { technique }\end{array}$ & Diabetes & $\begin{array}{l}\text { Adults } \\
(N=5)\end{array}$ & $\begin{array}{c}\text { Group CM put } \\
\text { together by the } \\
\text { educator during the } \\
\text { session }\end{array}$ \\
\hline $\begin{array}{l}\text { Balogoun, } \\
2008 \text { [14] }\end{array}$ & France & Thesis & $\begin{array}{l}\text { Qualitative } \\
\text { study }\end{array}$ & Diagnosis & $\begin{array}{l}\text { Multiple } \\
\text { myeloma }\end{array}$ & $\begin{array}{c}\text { Adults } \\
(N=3) \\
\text { Relatives } \\
(N=3) \\
\text { Caregivers } \\
(N=7)\end{array}$ & $\begin{array}{l}\mathrm{CM}+\text { interview by } \\
\text { the educator with } \\
\text { patient and relative, } \\
\text { joint map for } \\
\text { caregivers }\end{array}$ \\
\hline $\begin{array}{c}\text { Réberot } \\
\text { Amory } \\
\text { et al., 2008 } \\
{[40]}\end{array}$ & France & $\begin{array}{l}\text { Oral pre- } \\
\text { sentation } \\
\text { abstract }\end{array}$ & $\begin{array}{c}\text { Practical } \\
\text { experience }\end{array}$ & Diagnosis & Diabetes & Adults & $\begin{array}{l}\mathrm{CM}+\text { interview by } \\
\text { educator, before TPE }\end{array}$ \\
\hline $\begin{array}{c}\text { Delgado } \\
\text { et al., } 2008 \\
{[41]}\end{array}$ & Switzerland & $\begin{array}{l}\text { Oral pre- } \\
\text { sentation } \\
\text { abstract }\end{array}$ & $\begin{array}{l}\text { Qualitative } \\
\text { study }\end{array}$ & Assessment & $\begin{array}{c}\text { Diabetes + } \\
\text { cardiovas- } \\
\text { cular risk } \\
\text { factors }\end{array}$ & $\begin{array}{c}\text { Adults } \\
(N=14)\end{array}$ & $\begin{array}{l}\mathrm{CM}+\text { interview by } \\
\text { educator, before, after } \\
\text { and } 3 \text {-months after }\end{array}$ \\
\hline $\begin{array}{c}\text { Marchand } \\
\text { et al., } 2009 \\
{[25]}\end{array}$ & France & Article & $\begin{array}{l}\text { Qualitative } \\
\text { study }\end{array}$ & Assessment & Obesity & $\begin{array}{l}\text { Adults } \\
(N=13)\end{array}$ & $\begin{array}{c}\mathrm{CM}+\text { interview by } \\
\text { researcher, before and } \\
\text { after TPE }\end{array}$ \\
\hline
\end{tabular}


Table I. Continued. - Suite.

\begin{tabular}{|c|c|c|c|c|c|c|c|}
\hline $\begin{array}{l}\text { Marchand } \\
\text { et al., } \\
2009[27]\end{array}$ & France & Article & $\begin{array}{l}\text { Qualitative } \\
\text { study }\end{array}$ & Assessment & $\begin{array}{l}\text { Obesity } \\
\text { after } \\
\text { surgery }\end{array}$ & $\begin{array}{c}\text { Adults } \\
(N=24)\end{array}$ & $\begin{array}{l}\text { CM reviewed during } \\
\text { telephone interview, } \\
\text { by researcher, after } \\
\text { surgery }\end{array}$ \\
\hline $\begin{array}{l}\text { Ly Tang, } \\
2009 \text { [7] }\end{array}$ & $\begin{array}{c}\text { France } \\
\text { Polynesia }\end{array}$ & Thesis & $\begin{array}{l}\text { Practical } \\
\text { experience }\end{array}$ & Diagnosis & Asthma & $\begin{array}{l}\text { Children } \\
(N=2)\end{array}$ & $\begin{array}{c}\mathrm{CM}+\text { interview by } \\
\text { researcher }\end{array}$ \\
\hline $\begin{array}{c}\text { Bellantonio, } \\
2010[26]\end{array}$ & France & Thesis & $\begin{array}{l}\text { Practical } \\
\text { experience }\end{array}$ & Assessment & Diabetes & $\begin{array}{l}\text { Adults } \\
(N=3)\end{array}$ & $\begin{array}{l}\mathrm{CM}+\text { interview by } \\
\text { educator, before, } \\
\text { during and } 6 \text { months } \\
\text { after }\end{array}$ \\
\hline $\begin{array}{l}\text { Odier et al., } \\
2010 \text { [19] }\end{array}$ & France & Article & $\begin{array}{l}\text { Qualitative } \\
\text { study }\end{array}$ & Diagnosis & $\begin{array}{c}\text { Various } \\
\text { pathologies }\end{array}$ & $\begin{array}{l}\text { Adolescents } \\
(N=13)\end{array}$ & $\begin{array}{c}\mathrm{CM}+\text { emotions map } \\
+ \text { interview by } \\
\text { researcher }\end{array}$ \\
\hline $\begin{array}{l}\text { Chenuel, } \\
2011[42]\end{array}$ & France & Thesis & $\begin{array}{c}\text { Practical } \\
\text { experience }\end{array}$ & Diagnosis & Hemophilia & $\begin{array}{l}\text { Adolescents } \\
(N=5)\end{array}$ & $\begin{array}{c}\mathrm{CM}+\text { interview by } \\
\text { educator }\end{array}$ \\
\hline $\begin{array}{l}\text { Marchand } \\
\text { et al., } \\
2012[15]\end{array}$ & France & Article & $\begin{array}{l}\text { Quantitative } \\
\text { study }\end{array}$ & Diagnosis & $\begin{array}{l}\text { Various } \\
\text { pathologies }\end{array}$ & $\begin{array}{c}\text { Adults } \\
(N=16)\end{array}$ & $\begin{array}{l}\mathrm{CM}+\text { interview by } \\
\text { educator }\end{array}$ \\
\hline $\begin{array}{c}\text { Marchand } \\
\text { et al., } \\
2012 \text { [18] }\end{array}$ & France & Article & $\begin{array}{l}\text { Quantitative } \\
\text { study }\end{array}$ & Diagnosis & Diabetes & $\begin{array}{c}\text { Adults } \\
(N=30)\end{array}$ & $\begin{array}{l}\mathrm{CM}+\text { interview, } \\
\text { researcher }\end{array}$ \\
\hline $\begin{array}{c}\text { Levie, } 2012 \\
\text { [20] }\end{array}$ & France & Thesis & $\begin{array}{l}\text { Qualitative } \\
\text { study }\end{array}$ & Diagnosis & $\begin{array}{c}\text { Various } \\
\text { pathologies }\end{array}$ & $\begin{array}{l}\text { Adolescents } \\
(N=15)\end{array}$ & $\begin{array}{l}\mathrm{CM}+\text { emotion map + } \\
\text { interview, researcher }\end{array}$ \\
\hline $\begin{array}{l}\text { Giacomo, } \\
2012[8]\end{array}$ & France & Dissertation & $\begin{array}{l}\text { Qualitative } \\
\text { study }\end{array}$ & Diagnosis & Hypertension & $\begin{array}{c}\text { Adults } \\
(N=15)\end{array}$ & CM by patient alone \\
\hline $\begin{array}{l}\text { Gedeon, } \\
2013 \text { [43] }\end{array}$ & France & Dissertation & $\begin{array}{l}\text { Mixed } \\
\text { study }\end{array}$ & Diagnosis & Diabetes & $\begin{array}{l}\text { Parents of } \\
\text { children } \\
(N=35)\end{array}$ & $\begin{array}{l}\mathrm{CM}+\text { interview by } \\
\text { researcher }\end{array}$ \\
\hline $\begin{array}{l}\text { Bozorgzad } \\
\quad \text { et al., } \\
2013[21]\end{array}$ & Iran & Article & $\begin{array}{l}\text { Quantitative } \\
\text { study } \\
\text { RCT }\end{array}$ & $\begin{array}{c}\text { Educational } \\
\text { technique }\end{array}$ & Asthma & $\begin{array}{l}\text { Children } \\
(N=80)\end{array}$ & $\begin{array}{l}\text { CM as visual learning } \\
\text { aid (constructed by } \\
\text { educator before TPE) }\end{array}$ \\
\hline $\begin{array}{l}\text { Marchand } \\
\text { et al., } \\
2014[16]\end{array}$ & France & Article & $\begin{array}{l}\text { Qualitative } \\
\text { study }\end{array}$ & Diagnosis & $\begin{array}{l}\text { Cystic } \\
\text { fibrosis }\end{array}$ & $\begin{array}{c}\text { Adults } \\
(N=30) \\
\text { Carers } \\
(N=26) \\
\text { Caregivers } \\
(N=27)\end{array}$ & $\begin{array}{l}\mathrm{CM}+\text { interview by } \\
\text { researcher }+ \text { aid for } \\
\text { expressing barriers } \\
\text { and motivations }\end{array}$ \\
\hline $\begin{array}{c}\text { Person } \\
\text { et al., } \\
2014[10]\end{array}$ & France & Article & $\begin{array}{l}\text { Quantitative } \\
\text { study }\end{array}$ & Assessment & COPD & $\begin{array}{l}\text { Adults } \\
(N=7)\end{array}$ & $\begin{array}{l}\text { CM constructed by } \\
\text { educator after } \\
\text { interview (without the } \\
\text { patient), before and } \\
\text { after TPE }\end{array}$ \\
\hline
\end{tabular}

CM: Concept map/mapping; Educational follow-up is included under "Diagnosis", because CM is used for follow-up diagnosis when considering continuation of TPE; Here, "educational technique" is understood as a learning aid used during a TPE session; Mixed study: study with both qualitative and quantitative data; Oral presentation abstract: abstract of an oral presentation published in a journal; RCT: randomized controlled trial; COPD: chronic obstructive pulmonary disease.

- Sixteen were from journals, nine were theses or dissertations, and two were conference oral presentation abstracts.

- Twenty-one documents described studies: twelve used CM in qualitative studies; seven in quantitative studies (three of them randomized controlled trials); and two studies had both qualitative and quantitative data.

- Six documents described practical experience with concept mapping in TPE.

\subsection{Strengths, weaknesses and effects of each method, as indicated by authors}

\subsubsection{Population in which concept mapping was used}

Concept maps were used for TPE in a variety of audiences (Tab. I): adult patients (18/27), adolescents (3) or children (5), relatives and/or carers (4) and caregivers (2). The health 


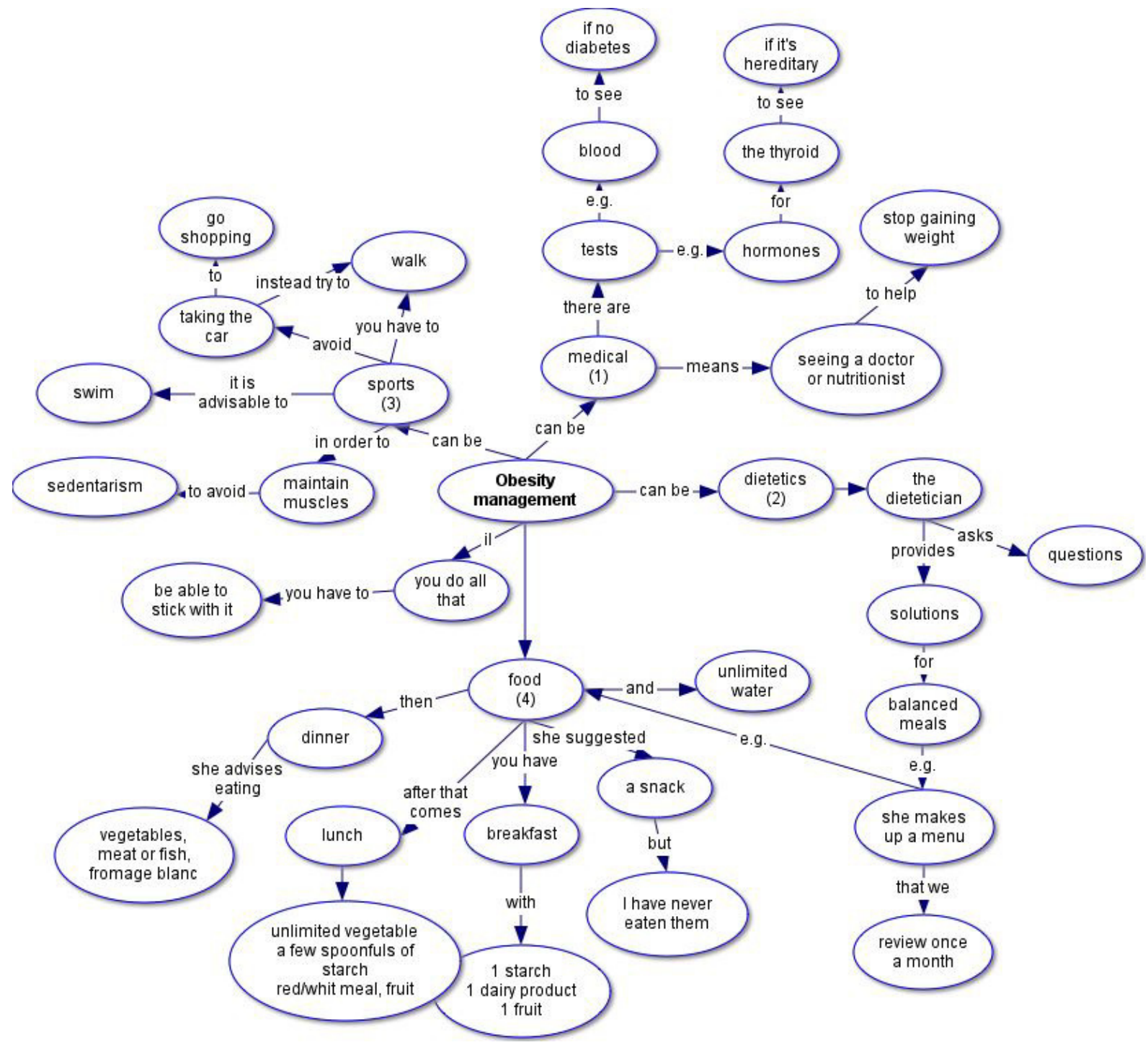

Figure 1. Example of a concept map, constructed during an interview from a central concept [25]. Exemple de carte conceptuelle, construite durant un entretien à partir d'un concept central [25].

problems and conditions involved were as follows: diabetes (8), multimorbidity (5), asthma (3), obesity (3), multiple myeloma/cancer (1), hemophilia (2), hypertension (1), cystic fibrosis (1), rheumatoid arthritis (1), chronic obstructive pulmonary disease (1), and hip replacement (1).

The authors do not indicate limits of use concerning the pathology or the age of the patient. However, it is likely that the patient's physical state and/or a too important cognitive or emotional load at the time of concept mapping could constitute limits.

\subsubsection{Methods for constructing concept map}

In the studies and practical experiences (Tab. I), the majority of concept maps (21/27) were constructed by the researcher or educator during an individual interview with a patient, carer or caregiver. The time taken to construct them ranged from 10 minutes to 1 hour and 40 minutes, with an average of approximately 30 minutes $[7,8]$. They usually started from a central concept or question. The authors stressed the difficult position of the interviewer (researcher or educator), who can influence the construction of the concept map during the interview $[8,9]$. The challenge was to encourage the patient to express his knowledge without influencing him. The interview techniques used to help construct the map were rarely described.

Other methods were also found. In one study, the educator used the concept map to summarize the information collected following the interview with the patient (out of the patient's presence) [10]. The authors stressed how difficult it was to use 
Search for articles and presentations published in English- and French-language journals from 2004 to 2014

ScienceDirect: 98, Google Scholar: 62, PubMed: 45, PsycINF0: 27

OpenGrey: 1, EM-Premium: 3, SUDOC: 6, ERIC: 0, JSTOR: 0

Documents identified: $N=\mathbf{2 4 2}$

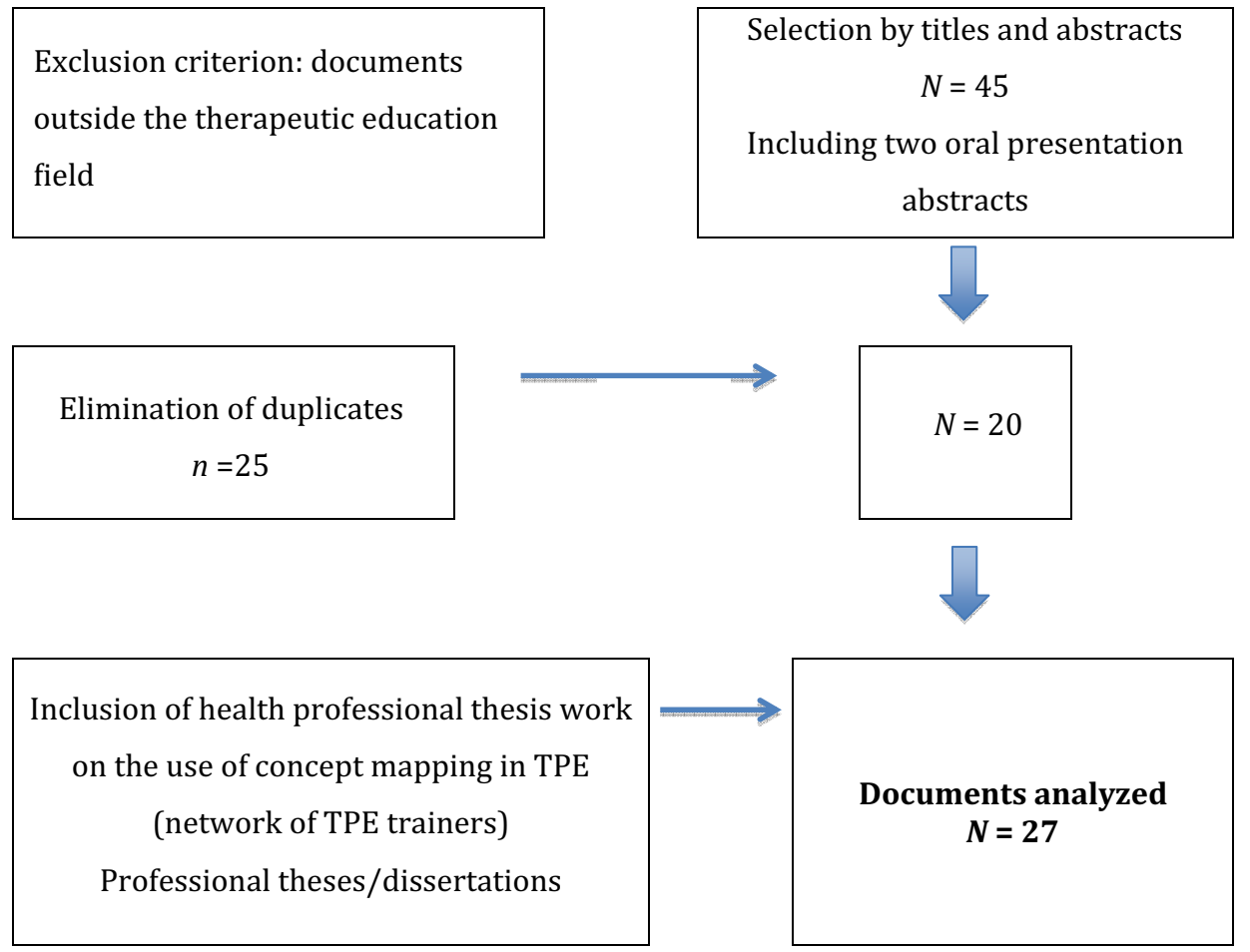

Figure 2. Flow chart. - Schéma de l'analyse de la litterature.

the concept map in this way in current TPE practice, due to the large amount of time required.

Three studies describe construction by the patient himself, followed by an interview with the researcher or educator $[8,11,12]$. According to the authors, the advantage of that method is that it prevents any distortion of the information, though there is a risk of not getting all of the desired information $[8,11]$. Time is still needed to help the patient express, in words, the links between the concepts, ideas and events, during the interview after the patient constructs the map [8]. Bonadiman et al. [12] reported their experience with concept mapping in general practice. They had asthma patients construct concept maps while in the waiting room, and then during the consultation that followed the doctor used what the patient produced to guide his consultation. Though patients were given an explanation beforehand, the problems encountered when they constructed their own concept maps were due to their lack of mastery of the technique or difficulty in writing down or formulating their thoughts.
In the study by Michaud et al. [9], the concept map was created during a group TPE session based on patient exchanges. The authors showed that the socio-cognitive conflict generated during this activity allowed each person to express his or her knowledge. Used in this way, the concept map allowed negotiation between the patients and educators over the meaning ascribed to the knowledge. The authors pointed out, however, that the presence of the educator may have limited the interactions between the participants. They suggested that it would be better to leave the group alone, but that would require giving the participants a significant amount of time to learn the technique.

In most of the documents analyzed, the authors recommended that the person who would be constructing the concept map (educator or patient) learn the technique beforehand. They also agreed that the choice of initial concept or question (indicating the area of knowledge to be explored) is a determining factor in the rest of the interview and construction of the map. 


\subsubsection{Purposes for which concept mapping was used}

For the documents as a whole (Tab. I), concept maps were used primarily for initial diagnosis (educational needs assessment) or educational follow-up (13/27). They were also used to assess the knowledge acquired by patients after therapeutic education (10/27). Their use as a learning aid during education sessions was more limited (4/27).

\section{- Concept mapping as diagnostic tool}

When concept maps are used to identify patient needs, knowledge or representations, they help:

- show the variety and richness of the patient's knowledge and representations [13-15], and can also reveal misconceptions [11], curbs or barriers to treatment [16];

- reveal any differences between the needs and priorities expressed by patients, carers and relatives and those determined by caregivers $[8,14-16]$. Patients and carers are most often concerned with the quality of daily life, and caregivers with knowledge of the disease and its treatment;

- identify cognitive or psychological problems in some patients $[17,18]$;

- give patients some perspective on their disease, allowing them a broader view of the situation, their experience, their emotions and their knowledge, and increasing their awareness, insight and ability to self-assess $[7,8,12,15,16]$. The authors suggest that this motivates patients to learn. Some even claim that using concept maps fosters empowerment [12];

- give adolescent patients a way to express and visualize their emotions $[19,20]$. Odier et al. [19] describe the following effects: they can be used for sharing and communication, facilitate the patient-caregiver relationship, focus the caregiver more on the patient, make the patient more aware of his knowledge and feelings by allowing him to verbalize them, giving him greater perspective about his disease. In the follow-up to that first study, Levie [20] tried to determine how expressing emotions can contribute to the process of transforming knowledge. The very preliminary results show that patients add to their concept map elements from the psychological and affective realms, some conditional knowledge and very little declarative knowledge. The author raises some methodological questions, in particular regarding how to question the patient when constructing the concept map.

- establish communication and start negotiations, for education sessions, in particular. Giacomo [8] views the concept map as a "third-party mediator" between the patient and caregiver;

- provide a written record for the patient's file that can be used later to see any progress and changes $[8,12,14]$.

Becoming aware of patient acquisitions and needs is not only helpful in centering the care on the patient and meeting his expectations, but also in adapting and improving patient education programs $[7,13,18]$.

\section{- Concept mapping as a learning aid during education sessions}

Michaud et al. [9] used concept mapping as a learning aid during an education session. In that study, the assessments done before and after the session using a knowledge questionnaire with degree of certainty showed that using a concept map during a group education session increased the patients' knowledge and especially, their certainty about their knowledge. Moreover, the technique generated many interactions between the participants, most likely favorable to learning, according to the authors [9]. In a randomized study among 80 children with asthma, Bozorgzad et al. [21] measured the impact of education on quality of life (Quality of Life Questionnaire). They compared one group receiving education with concept mapping as an aid to learning the spray technique to a group without mapping. The results showed better quality of life for the children who were educated with the concept map. The same results were found in Johansson et al. 's randomized study [22] of 123 patients who needed surgery for osteoarthritis of the hip. The group that received education using concept mapping had better results than the group without CM. In that study, the concept map was constructed with the patient as part of an individual education visit favoring patient interaction. Those authors claimed that the concept map was a good way to add to the patients' knowledge and foster empowerment. In contrast, Walker et al. [23] found no difference in their randomized study of 363 patients. The education used either a booklet combined with a mind map-type visual aid, or the booklet alone. The objective was to see whether the mind map improved comprehension in patients with low health literacy. Both patient groups improved their knowledge, but there was no significant difference between the two groups. In particular, the authors stressed that the mind maps did not help solve the problems of people with reading difficulties.

\section{- The concept map as an assessment tool for patient learning}

Several authors [17, 24-28] agreed that concept maps allow visualization of any learning that has occurred by identifying changed or added knowledge on the concept map, and the preservation or lack of knowledge immediately [17,24-28] or some time $[27,28]$ after education. In addition, they provide information on how knowledge is organized during education. For example, in 2007, Marchand et al. [28] did a study that used concept maps to look at the changes in and organization of knowledge in five 8- and 9-year-old diabetic children and their mothers both before and some time after therapeutic education sessions. The results showed that while both the children and their parents acquired knowledge, there were differences in the nature and organization of that knowledge, due not just to differences in their concerns, but also to the fact that "child patients learn differently".

Limitations have been found in the ability of concept maps to systematically explore knowledge in a particular domain [25]. Indeed, the authors assert that "the interview technique and questions asked by the interviewer inevitably 
influence the orientation (in terms of content) and nature of the information obtained, which makes the assessment less reliable" [25]. According to the same authors, however, concept maps have "unquestionable validity" in helping to "demonstrate the learning processes", unlike the other assessment tools in therapeutic education [25].

\section{Discussion}

This literature analysis offers a summary of how concept mapping has been used in the field of therapeutic patient education over the past ten years and raises questions about several aspects of their use and effects.

\subsection{Concept maps used at different stages of TPE}

The documents analyzed show that they have a place in each stage of the TPE process [29]: the educational needs diagnosis, the negotiation of a contract, the educational technique, the assessment of the patient's knowledge and the patient follow-up. We also found them being used to identify differences and similarities in terms of the needs, priorities and conceptions of the various actors (patients, carers and caregivers), and as an aid in expressing emotions.

As an assessment tool, concept maps make it possible to visualize how learners organize and prioritize their knowledge - something other tests cannot evaluate [30]. Their relevance and content validity for that purpose have been recognized for training and diagnostic assessment [31]. And while the authors do not believe that the psychometric qualities of concept mapping are sufficient for certification assessment in general education, the latter is not an issue in therapeutic patient education.

This study does, however, show that concept maps do not seem to be used much, if at all, as a learning aid for either individuals or groups. The review identified only one exploratory study looking at their use in groups [9]. Yet in another discipline, Pudelko et al. [32] showed that having a group of learners (students) construct a concept map potentiates their learning, especially if combined with other strategies like group work and/or feedback. However, those same authors caution against confusing the impact of concept mapping with that of the teaching techniques with which it is combined, i.e., collaborative learning, feedback and scaffolding. In their critical review of the literature, they suggest that concept mapping, in itself, does not improve meaningful learning any more than do teaching techniques requiring similar cognitive engagement.

There are several hypotheses to explain why concept maps are underutilized as a learning aid. The first has to do with the time required to construct a concept map, as pointed out by several authors [8-10]. In France, despite the political recognition of TPE, the time devoted to it is often limited for organizational and human resource-related reasons. Yet according to Jouquan [33], these time constraints related to concept mapping and feedback "are a non-problem. Whatever the medium, in-depth, meaningful learning is a demanding cognitive task for students, just as is the teachers' task of giving them the supervision they need to succeed. If those are indeed each group's objectives, the time spent on it is irreducible". The second hypothesis concerns the training for professionals doing TPE. Most authors emphasize the need to be trained in the use of concept mapping $[9,11,12,15,16]$. Its use in TPE is likely conditioned by the orientation of the training, which itself depends on the trainer's profile. In other words, without a guarantee that TPE training is really based on a pedagogical approach the place accorded to discovering and practicing concept mapping during such training will probably be rare and - in the absence of international recognition - dependent on whether the trainer regards $\mathrm{CM}$ as useful.

\subsection{Little exploration of CM's effects on patients}

While the published studies on concept mapping in TPE report its benefits, few publications with a high-enough level of evidence have demonstrated its effect on patients learning and self care. The methodological difficulty in conducting randomized controlled trials on complex interventions that include education might explain, at least in part, these findings [34].

The studies that were found had varying results with regard to the effects of using concept mapping on patients [21-23]. That variability was due, in part, to the fact that different effects were being measured; two studies looked at the effects on knowledge [22,23], and a third looked at the impact on quality of life [21]. None of the studies allowed measurement of concept mapping's effects on patients' problem-solving skills. However, in their literature analysis on the use of concept mapping in medical education, Daley and Torre [35] showed that concept maps helped improve critical thinking and problemsolving, regardless of the learner's learning style. Recently, Demeester demonstrated the value of concept mapping in the acquisition of clinical reasoning skills [31].

It might be possible to transfer these results to therapeutic education. Given that the organization of knowledge determines, in part, how it can be used to solve a problem or make a decision, and that the organization of knowledge in long-term memory is - as Bordage and Lemieux [36] point out - a characteristic that distinguishes experts from novices, we might wonder whether the use of concept mapping as a teaching tool would help improve patients' problem-solving. Further research should allow us to explore such effects more specifically.

The variability of the results is also explained by the fact that the methods for using concept maps in the three randomized controlled trials were not comparable; in one study [22], the concept map was constructed through interaction with the patient, suggesting feedback activity during a two-person construction process, while in the two other studies [21,23] it was constructed by the educator beforehand as a visual aid to learning. In other fields - like biology [37], for example - concept mapping combined with feedback resulted in improved student problem-solving and a lower error rate, an effect not found in the group for which concept mapping was not added to feedback. Educator feedback after concept mapping and its effects on patient learning have not been explored in the field of therapeutic patient education. 
Lastly, in 2004, Marchand and d'Ivernois [3] pointed out the potential of concept mapping to help patients look at themselves and assess their own knowledge. Those authors claimed that constructing a concept map with patients prompted them to doubt and question their knowledge, motivating them to learn. They also suggested that concept mapping increased patients' metacognition, helping them give meaning to their learning and giving them a better overall view of their knowledge. While the documents analyzed $[7,8,12,15,16]$ often mentioned metacognitive aspects such as patients' awareness and overall view of their knowledge set, and the greater perspective on what patients know, they did not describe the metacognitive process or its effect on patient learning.

\subsection{Greater use of CM in TPE should be encouraged}

The number of publications on concept mapping is relatively small compared to the growing number of publications in the field of therapeutic patient education [38]. In general, studies aimed at proving TPE's effectiveness or efficiency usually rely on clinical, paraclinical or psychosocial parameters. They are much less interested in the added value of one particular learning aid over another. This is explained by the fact that the authors are frequently caregivers whose main aim is to improve health. Concept mapping is no exception to this, which is why the results are so limited.

The vast majority (21/27) of documents selected for this review were from studies done in France, and two thirds of them were written in French, which might explain the limited use of CM in TPE internationally. However, inasmuch as concept mapping is a technique developed in the United States and supported by the Institute for Human and Machine Cognition (IHMC), we might wonder why it is not used more in patient education by North American research teams or practitioners.

These results raise some questions about the place and future of concept mapping in therapeutic patient education Judging from the number of articles published since 2004, its use is still modest, despite the educational benefits demonstrated in other disciplines. However, and this is perhaps a limitation of this study, the impossibility of conducting an exhaustive review of theses and dissertations prevents us from knowing whether interest in concept mapping is growing, thanks to training environments preparing future researchers and practitioners to use it. On the other hand, this teaching tool could quickly capture the community's interest once there is real recognition that living with a chronic disease is a significant act of learning for the individual.

\section{Conclusion}

This study is the first to describe, based on the literature, how concept maps are being used in therapeutic patient education roughly ten years after being introduced in the field. It shows that concept maps are used primarily for diagnostic and assessment. In most of the documents analyzed, concept maps were constructed in the course of an interview. We found few publications on the use of concept mapping as a learning aid, though there is a rich literature in other fields on its effects on learning.

The results show how difficult it is for a technique to find a place in the TPE field. Its use is very likely contingent on the growth of TPE and, as a result, on the recognition that taking care of oneself is an act of learning that requires specific support and interventions. That raises questions about the objectives and contents of TPE training.

To better understand the adoption of an educational innovation like concept mapping in TPE, it might be helpful to supplement this literature analysis with a field study to better describe the educational, environmental and organizational factors conditioning the use of concept maps in TPE practice.

Conflicts of interest. The authors declare no conflict of interests concerning the data published in this article.

\section{References}

1. Novak J, Gowin DB. Learning how to learn. New York: Cambridge University Press; 1984.

2. Nesbit JC, Adesope OO. Learning with concept and knowledge maps: A meta-analysis. Rev Educ Res 2006; 76:413-448.

3. Marchand C, Ivernois (d') JF. [Concept mapping in health education]. Pédagogie Médicale 2004; 5:230-240.

4. Marchand C, Ivernois (d') JF, Assal JP, Slama G, Hivon R. An analysis, using concept mapping, of diabetic patients' knowledge, before and after patient education. Med Teach 2002; 24:90-99.

5. França S, Marchand C, Craplet C, Basdevant A, Ivernois (d') JF. Application of "Concept Mapping" in obese subjects: a pilot study in normo and underreporters. Diabetes Metab 2003; 29:7278.

6. Haute Autorité de Santé (HAS). [Recommendations Therapeutic patient education: How to offer it and do it] 2007 [consulted on July 8, 2015].

Disponible sur : http://www.has-sante.fr/portail/upload/docs/ application/pdf/etp_-_comment_la_proposer_et_la_realiser_-_ recommandations_juin_2007.pdf

7. Ly Tang L. Mise en œuvre de la carte conceptuelle chez l'enfant polynésien atteint de maladie respiratoire chronique. Mémoire professionnel de formation continue - en ligne 2009 [consulté le 28 janvier 2014]. Disponible sur : http://www.ipcem.org/ RESSOURCES/PDFprim/0882.pdf

8. Giacomo V. [How concept maps contribute to co-construction of the shared educational needs assessment: qualitative study with hypertensive patients] [Practice thesis] Nice : Université de NiceSophia Antipolis. Faculté de médecine; 2012.

9. Michaud J-P, Marchand C, Pignat IB, Ruiz J. [Concept mapping in therapeutic patient education with a group of diabetic patients : pedagogical advantages] Education du Patient et Enjeux de Santé 2008; 26:12-17.

10. Person M, Beaumont M. [Use of conceptual maps for the evaluation of the patients'knowledge in pulmonary rehabilitation]. Kinésithérapie Rev 2014; 14:53-59.

11. Arnal C. [The usefulness of concept maps constructed by hemophiliac children themselves in assessing changes in their knowledge in the context of therapeutic education] [Master's thesis]. Bobigny : Université Paris 13 Sorbonne Paris Cité; 2006. 
12. Bonadiman L, Gagnayre R, Marchand C, Marcolongo R. [The use of concept mapping in medical consultation]. Education du Patient et Enjeux de Santé 2006; 24:46-50.

13. Marchand C, Poitou C, Pinosa C, Dehaye B, Basdevant A, Ivernois (d') JF. Cognitive structures of obese patients undergoing bariatric surgery: a concept mapping analysis. Obes Surg. 2007; 17(10):1350-6.

14. Balogoun G. [Educational needs of patients with myeloma and their families for the "implementation of a TPE program" : preliminary analysis] [Master's thesis]. Bobigny : Université Paris 13, Sorbonne Paris Cité; 2008.

15. Marchand C, Amory-Rébérot B, Van der Schueren Etévé M, Proust N, Ruelle L, Taupin J-M, et al. [Advantages of concept mapping in the long-term educational follow up of patients in a specific educational structure]. Educ Ther Patient/Ther Patient Educ 2012; 4(1):31-40.

16. Marchand C, Salhi L, Le Rhun A, Ravilly S, Danner-Boucher I, Gagnayre R, et al. [Perceptions of cystic fibrosis patients, patient relatives and physicians: Barriers or motivations to lung transplantation]. Rev Mal Respir 2014; 31(3):237-247.

17. França S, Ivernois (d') JF, Marchand C, Haenni C, Ybarra J, Golay A. Evaluation of nutritional education using concept mapping. Patient Educ Couns 2004; 52(2):183-192.

18. Marchand C, Ciangura C, Griffe V, Pinosa C, HaVan G, Hartemann A, et al. Barriers to preventive and curative foot care behaviors in person with diabetes. Suggestions for therapeutic patient education. Educ Ther Patient/Ther Patient Educ 2012; 4(2):S135-142.

19. Odier A, Marchand C, Leger P, Gagnayre R. Highlighting emotions through concept mapping: an exploratory study of adolescent patients. Educ Ther Patient/Ther Patient Educ 2010; 2(2):S139-S147.

20. Levie J. [Objectivation of emotions and the process of transforming the knowledge of adolescent patients with chronic illnesses] [Master's thesis]. Bobigny : Université Paris 13, Sorbonne Paris Cité; 2012.

21. Bozorgzad P, Ebadi A, Moin M, Sarhangy F, Nasiripour S, Soleimani MA. The effect of educating the use of spray by visual concept mapping method on the quality of life of children with asthma. Iran J Allergy Asthma Immunol 2013; 12:63-67.

22. Johansson K, Salanterä S, Katajisto J. Empowering orthopaedic patients through preadmission education: results from a clinical study. Patient Educ Couns 2007; 66:84-91.

23. Walker D, Adebajo A, Heslop P, Hill J, Firth J, Bishop P, et al. Patient education in rheumatoid arthritis: the effectiveness of the ARC booklet and the mind map. Rheumatol Oxf Engl 2007; 46(10):1593-1596.

24. Pinosa C, Marchand C, Tubiana-Rufi N, Gagnayre R, Albano M, Ivernois (d') JF. The use of concept mapping to enlighten the knowledge networks of diabetic children: a pilot study. Diabetes Metab 2004; 30(6):527-5234.

25. Marchand C, Choleau C, Ivernois (d') JF, Reach G. [Evaluation of Therapeutic Patient Education with concept mapping in obese patients before surgery]. Educ Ther Patient/Ther Patient Educ 2009; 1:S109-S117.

26. Bellantonio V. Evaluer les connaissances du patient participant à l'éducation diététique, au sein du réseau Marseille-Diabète [Mémoire professionnel de formation continue- en ligne]. 2010 [consulté le 28 janvier 2014]. Disponible sur: http://www.ipcem. org/RESSOURCES/annumem.php?id=736 \\&n=0
27. Marchand C, Poitou C, Pinosa C, Harry I, Basdevant A, Ivernois (d') JF. Using concept maps to describe the evolution in obese patients' knowledge and expectations following bariatric surgery. Educ Ther Patient/Ther Patient Educ 2009; 1:49-55.

28. Marchand C, Crozet C, Martin D, Robert JJ, Ivernois (d') JF, [A concept mapping study of nutritional knowledge in diabetic children and their parents]. Rev Med Suisse 2007; 3:868-872

29. Ivernois (d') JF, Gagnayre R. [Learning to educate patients: a pedagogical approach]. Paris: Maloine; 2011.

30. Marchand C, Hivon R, Ivernois (d') JF. [Knowledge evaluation with concept mapping in diabetic patients : methodological approach]. Mesure et Évaluation en éducation 2001; 24:27-43.

31. Demeester A, Vanpee D, Marchand C, Eymard C. [Clinical reasoning learning: concept mapping as a relevant strategy]. Pédagogie Médicale 2010; 11:81-95.

32. Pudelko B, Young M, Vincent-Lamarre P, Charlin B. Mapping as a learning strategy in health professions education: a critical analysis. Med Educ 2012; 46:1215-1225.

33. Jouquan J. [If you please,... draw me your knowledge!] Pédagogie Médicale 2010; 11:77-79.

34. Clark AM. What are the components of complex interventions in healthcare? Theorizing approaches to parts, powers and the whole intervention. Soc Sci Med 1982 2013; 93:185-193.

35. Daley BJ, Torre DM. Concept maps in medical education: an analytical literature review. Med Educ 2010; 44:440-8.

36. Bordage G, Lemieux M. Semantic structures and diagnostic thinking of experts and novices. Acad Med J Assoc Am Med Coll 1991; 66:S70-S72.

37. Morse D, Jutras F. Implementing Concept-based Learning in a Large Undergraduate Classroom. CBE Life Sci Educ 2008; 7:243-253.

38. Albano MG, Deccache A, Godibile A, Ivernois (d') JF. Development of publications on patient education in chronic diseases from 1999 to 2009. Educ Ther Patient/Ther Patient Educ 2009; 1:S101-S107.

39. Rébérot-Amory B. L'utilisation des cartes conceptuelles dans l'accompagnement éducatif?: Point de vue des patients diabétiques, Point de vue des soignants. [Mémoire professionnel de formation continue - en ligne] 2004 [consulté le 28 janvier 2014]. Disponible sur : http://www.ipcem.org/RESSOURCES/ annumem.php?id=525 \\&n=0

40. Rébérot-Amory B, Taupin JM, Proust N, Floury I, Eteve-Van de Schueren M. [The use of concept mapping in providing educational support for patients with Type 2 diabetes]. Diabète Education 2008; No. spécial congrès du $1^{\text {er }}$ février $2008: 17$.

41. Delgado H, Sofra D, Lehmann T, Golay A. [The "concept map": a tool for training assessment and patient follow-up]. Diabetes Metabolism 2007;33(No. spécial 1):154.

42. Chenuel C. Mise en œuvre de la carte conceptuelle dans le diagnostic éducatif des adolescents ou préadolescents atteints d'hémophilie. [Mémoire professionnel de formation continue - en ligne] 2011 [consulté le 28 janvier 2014]. Disponible sur : http://www.ipcem.org/RESSOURCES/ annumem.php?id=787\\&n=0

43. Gédeon R. [Therapeutic education stay for children with Type 1 diabetes and their parents: an analysis of parents' expectations and impact on their quality of life] [Practice thesis]. Clermont Ferrand : Université de Clermont I, 2013. 